
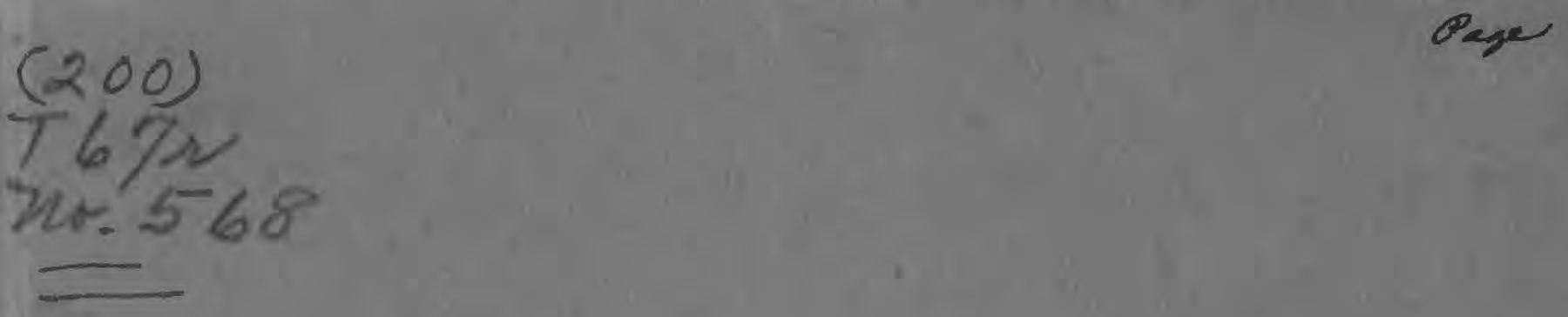

AN IMPROVED GLASS SAMPLE HOLDER FOR

A S S A ING LOW RADIOACTIVITY SAMPLES

By F. J. Flanagan and B. A. McCall

Trace Elements Investigations Report 568

UNITED STATES DEPARTMENT OF THE INTERIOR GEOLOGICAL SURVEY 


\section{UNITED STATES \\ DEPARTMENT OF THE INTERIOR \\ GEOLOGICAL SURVEY \\ WASHINGTON 25, D. C.}

AEC $-330 / 6$

December 5, 1955

Mr. Robert $D$. Nininger, Assistant Director

Division of Raw Materials

U. S. Atomic Energy Commission

Washington 25, D. C.

Dear Bob:

Transmitted herewith are three copies of TEI-568, "An improved glass sample holder for assaying low radioactivity samples," by F. J. Flanagan and B. A. McCall, September 1955.

We are asking $\mathrm{Mr}$. Hosted to approve our plan to submit this report for publication in Analytical Chemistry, Aids to the Analyst. Sincerely yours,

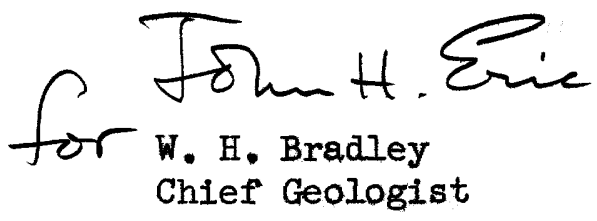




$$
\begin{aligned}
& (200) \\
& 672 \\
& 20.5468
\end{aligned}
$$

Geology and Mineralogy

This document consists of 7 pages. Series A.

UNITED STATES DEPARTMENT OF THE INTERIOR

GEOLOGICAL SURVEY

AN IMPROVED GLASS SAMPLE HOLDER FOR ASSAYING

LOW RADIOACTIVITY SAMPLES*

By

F. J. Flanagan and B. A. McCall

September 1955

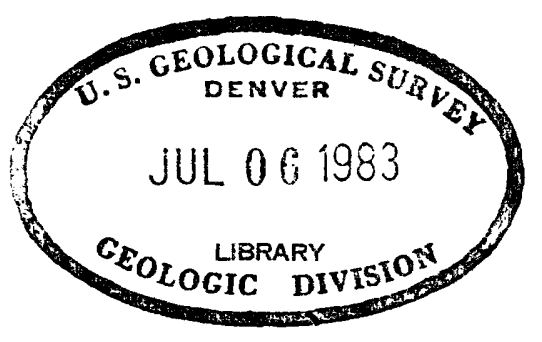

Trace Elements Investigations Report 568

This preliminary report is distributed without editorial and technical review for conformity with official standards and nomenclature. It is not for public inspection or quotation.

*This report concerns work done on behalf of the Division of Raw Materials of the U. S. Atomic Energy Commission. 
USGS - TEI-568

\section{GEOLOGY AND MINERALOGY}

Distribution (Series A)

Argonne National Laboratory

No. of copies

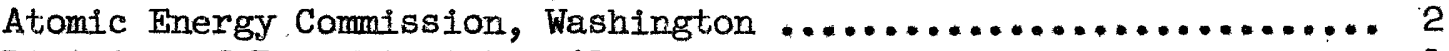

Division of Raw Materials, Albuquerque ..................... I

Division of Raw Materials, Butte ........................... I

Division of Raw Materials, Casper ......................... I

Division of Raw Materials, Denver .......................... I

Division of Raw Materials, Hot Springs ..................... I

Division of Raw Materials, Ishpeming ...................... 1

Division of Raw Materials, Phoenix ........................ I

Division of Raw Materials, St. George ....................... I

Division of Raw Materials, Salt Lake City ................... I

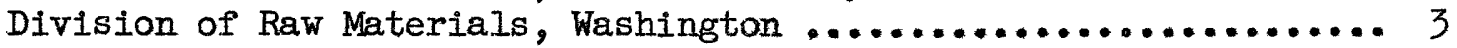

Exploration Division, Grand Junction Operations Office .......... I

Grand Junction Operations Office ......................... 1

Technical Information Service, Dak Ridge .................... 6

U. S. Geological Survey:

Fuels Branch, Washington .............................. I

Geochemistry and Petrology Branch, Washington ................20

Geophysics Branch, Washington .......................... 1

Mineral Deposits Branch, Washington ........................ I

E. H. Bailey, Menlo Park ................................ I

A. I. Brokaw, Grand Junction ............................ I

N. M. Denson, Denver ................................. I

L. R. Griggs, Albuquerque $\ldots \ldots \ldots \ldots \ldots \ldots \ldots \ldots \ldots \ldots \ldots \ldots \ldots \ldots \ldots \ldots \ldots$

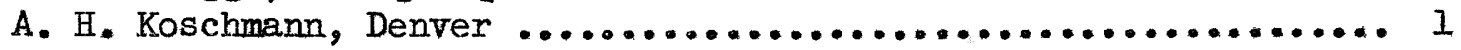

I. R. Page, Washington ................................ 1

Q. D. Singewald, Beltsville ........................... I

A. E. Weissenborn, Spokane ................................ 1

THPCO, Denver .......................................... 2

TEPCO, RPS, Washington, (including master) $\ldots \ldots \ldots \ldots \ldots \ldots \ldots \ldots \ldots$ 


\title{
AN IMPROVED GLASS SAMPLE HOLDER FOR ASSAYING LOW RADIOACTIVITY SAMPLES
}

\author{
By F. J. Flanagan and B. A. McCall
}

\section{ABSTRACT}

An improved sample holder for measuring the radioactivity of powdered samples. consists of a thin-walled Geiger-Mueller tube, a ground-glass joint, and a four-pin connector.

The coaxial sample holder technique has been used by the U. S. Geological Survey to determine the radioactivity of low-grade uranium ores. Routine radioactivity measurements of about 25,000 powdered samples per year have been made using a holder of this type both by manual operation and as an integral part of a modification to the Tracerlab automatic sample changer previously described (Flanagan and others, 1950). The sample holder differs from others (Gaudin and Pannell, 1948; Senftle, 1948) in that: (a) no machining is required to make the unit; (b) the sample is in contact with the tube wall; and (c) the conventional lead shield has been eliminated. However, the usefulness of this holder is reduced somewhat by breakage of the pigtail leads of the Geiger tube and the uncertainties in reproducibility of sample position. The design described below has given the best results in terms of reproducibility of sample position and the number of determinations per tube.

A ground-glass joint with a thin-walled Geiger-Mueller tube aligned coaxially by rubber stoppers is shown in the inverted position ready for 
the pouring of the resin in figure 1. Sufficient resin should be poured into the male part of the joint to cover the glass portions of the Geiger tube. The upper stopper, whose functions are to align the tube and to retain the resin in place until hard, is shown partly cut away to indicate the relative positions of the edges of the Geiger tube cathode and. of the male joint. This arrangement keeps the required amount of sample at a minimum.

All surfaces which the resin should bond must be free from grease. The thin-walled section of the Geiger tube should be generously lubricated before an attempt is made to remove the aligning stopper. After this stopper is removed, the small void remaining should be filled with resin flush to the end of the male joint. A four-pin connector is attached at the base of the joint to the pigtail leads and the unit is ready for operation. The unit is used for powdered samples but may be used for liquids (except organic solvents and alkaline solutions which remove the black lacquer covering the Geiger tube) if the ground-glass joint is lubricated.

A $34 / 45$ standard taper joint with a $30 \mathrm{mg} / \mathrm{cm}^{2}$, 3-inch cathode Geiger. Muellertube is used because many of the samples received are small (about 90-100 grams). By use of this size joint we approach but do not equal infinite $\beta$ cthickness for our samples. The unit is held on a ring stand by a utility clamp and connected to a conventional scaler. The tube is normally operated without a lead shield; this results in an increase of background by a ratio of 2.5 to 1 , but the counting rate of the unit compared. to that of the conventional end.window technique is approximately 6 to 1 . 


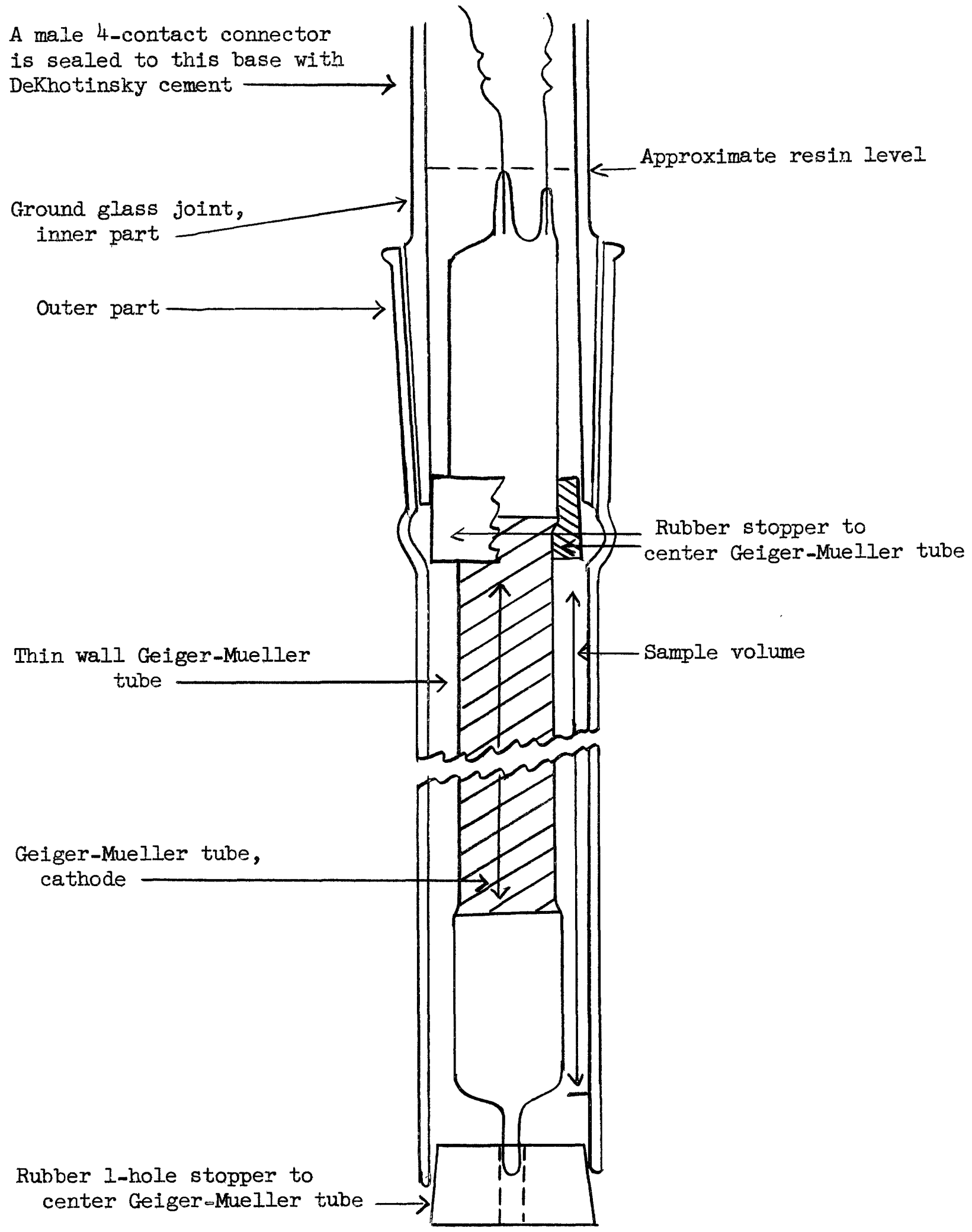

Figure 1.--Tube and sample holder ready for pouring of resin. 
Measurements are made by pouring the powdered sample into the top of the assembled unit, tapping lightly to compact the sample, and counting the system for the time desired. To empty, the unit is inverted and tapped lightly to discharge all the material. For routine counting of material of approximately the same type and the same activity the unit is not cleaned between determinations. Contamination due to the small amount of powdered sample remaining on the glass surfaces has had no detectable effect on succeeding samples.

The unit is standardized by counting standards in which the amount of uranium has been determined chemically and in which thorium and potassium are present in such small amounts as to cause no interference. The usual assumptions are made that (I) all the radioactivity of the sample is due to uranium and its daughter products, and (2) the uranium is in secular equilibrium with its daughter products. Although these two assumptions may not be true, they allow us to calculate radioactivity measurements in terms of percent equivalent uranium (eU), that is, the radioactivity which is equivalent to that shown by a specified percentage of uranium in equilibrium with its daughter products. Errors due to different powder densities may be corrected by multiplying by the ratio of sample to standard weights.

This holder is most useful for determining in very short time ( $I$ to 5 minutes) the radioactivity of rock samples in the range 0.001 to 0.1 percent eU. The range may be extended to 0.0001 percent by lengthening the counting time. In this laboratory counting intervals of 2 and 5 minutes are used for all routine samples, the longer time being used where slightly better precision is required. The precision obtainable in the low range of uranium 
content can be seen from data obtained during an internal standardization of a shale sample using counting times of 5 minutes. The results show that the sample has a mean radioactivity of 0.0058 percent eU with an unbiased estimate of the standard deviation of 0.00016 percent eU or \pm 2.8 percent of the mean value.

This study is part of a program being conducted by the U. S. Geological Survey on behalf of the Division of Raw Materials of the U. S. Atomic Energy Commission.

\section{REFERENCES}

Flanagan, F. J., Nelson, J. M., and Warr, J. J., Jr., 1950, Modification to Tracerlab automatic sample changer: Ra-Det, v. 3, no. 7 , p. 14 .

Gaudin, A. M., and Pannell, H. H., 1948, Radioactive determination of potassium in solids: Anal. Chemistry, v. 20, p. 1154.

Senftle, F. E., 1948, Radioassay of low grade uranium and thorium ores, Progress Report Ia - The annulus counter, Canada Department of Mines and Resources, Bureau of Mines. 